\title{
Ethanolic Leaf Extract of Gymnema sylvestre Ameliorates Hyperglycemia and Pancreatic Oxidative Stress in Alloxan induced Diabetic Rats
}

\author{
Research Article
}

\section{Kumud Ranjan Thakur1*, Shree Ram Padmadeo², Annpurna Kumari ${ }^{3}$}

\author{
1. PhD Scholar at Department of Biochemistry, Patna University, Patna. \\ 2. Dean, Faculty of Science, and Principal, Patna Science College, Patna University, Patna. \\ 3. Visiting faculty, Department of Biochemistry, Patna University, Patna.
}

\begin{abstract}
Diabetes mellitus (DM) is a serious metabolic disorder with altered carbohydrate, fat, and protein metabolism. In the last four decades, India has emerged as an epicenter of the global diabetes mellitus pandemic. Rapid changes in the developmental scenario, demographic changes, and living style in the Indian subcontinent have led to the explosive increase in diabetes. Present research probes with ethanolic extract of Gymnema sylvestre (500 $\mathrm{mg} / \mathrm{kg} . \mathrm{b} . \mathrm{w})$ for treatment of hyperglycemia and related oxidative stress caused by Alloxan $(100 \mathrm{mg} / \mathrm{kg}$.b.wt), as a diabetogenic agent. 25 rats were included in the research divided into 5 groups, each containing 5 rats. Group 1 (normal rats), Group II (Diabetic rats (DM), Group III (DM+ treated for 10 days), Group IV (DM+20 days treated), Group V (DM+30 days treated). Blood samples and pancreatic tissues were collected at each interval of time. The blood sample was used for biochemical parameter and tissues were used for the anti-oxidant assay. Gymnema sylvestre extract (GSE) showed glucose-lowering property meanwhile, insulin secretion also increased as compared to Diabetic rats. Other tests like amylase, lipase, ALT, and AST also showed significant recovery after the extract administration. Oxidative stress was found in the Diabetic group, but after extract treatment concentration of superoxide dismutase, Glutathione-S-transferase, catalase, Glutathione peroxidase, Glutathione, and Total thiol was regained. Imbalance in serum electrolyte recovered and dysregulated hematological parameters due to stress and hyperglycemia showed convincing results. The finding suggests Gymnema sylvestre could be used as a hypoglycemic as well as an anti-oxidant agent in diabetes.
\end{abstract}

Key Words: Diabetes, Gymnema sylvestre, Anti-oxidant, Hyperglycemia, Acute pancreatitis, Alloxan.

\section{Introduction}

Diabetes mellitus is a serious metabolic disorder with altered carbohydrate, fat, and protein metabolism. There are currently 425 million people with diabetes worldwide, and this number is expected to reach 629 million by 2045, with type 2 diabetes (T2DM) being the most expressive form of the disease $(1,2)$.

India ranks second after China with highest number of people suffering from this epidemic globally with another serious prevalent shifting from urban to rural and from older to younger age group (3).

High glucose concentration also promotes advanced glycosylated end products (AGEs). These AGEs in association with persistent hyperglycemia

* Corresponding Author:

Kumud Ranjan Thakur

PhD Scholar,

Department of Biochemistry,

Patna University,

Patna, India

Email Id: kumudrnj@rediffmail.com stimulates free radical, and reactive oxygen species (ROS) formation. Oxidative stress has a significant role in further complications of type 2 Diabetes Mellitus. An increase in ROS level leads to elevated or dysregulated production of antioxidants like catalase, superoxide dismutase, glutathione peroxidase, etc (4). The variation in the availability of the mentioned parameters pronounces the tissue susceptibility to the oxidative stress pertaining to the appearance of diabetes and its associated complications (5).

In the present research Alloxan was used as a Diabetogenic material due to its specificity for the $\beta$ cell destruction. Alloxan causes diabetes by partial degradation of $\beta$ - cell of pancreatic islets results in compromised quality and quantity of insulin by these cells. The animal model under investigation is targeted by two pathological effects which include selective inhibition of glucose-stimulated insulin secretion and the formation of reactive oxygen species (ROS) which promotes necrosis of $\beta$ - cell (6). Necrosis causes cellular membrane damage results in to release of intracellular content and inflammation. In previous studies, it is found that acute pancreatitis with 
deregulated amylase and lipase concentration is prevalent due to this inflammatory response $(7,8)$.

Treatment with the synthetic drug is confined to mono target site and the market is flooded with such synthetic drugs. In such condition herbal remedy for the diabetes has been a consistent, less expensive and alternative method over existing synthetic drugs (9). The positive outcome of the phytomedicines with low cost and negligible side effect has revolutionized the drug discovery concept and diabetes management strategies (10).

Gymnema sylvestre is one such herb which shows tremendous hypoglycemic properties with remarkable antioxidant potential. It belongs to Asclepiadaceae family predominantly found in India, China, Australia, and Africa. Its popular name is "gurmar" due to its glucose lowering property. Gymnema sylvestre is considered as a prominent botanical for diabetes management since Ayurvedic era (11).

\section{Materials and methods}

For the present research work healthy wistar rats (Rattus norvegicus) of weight ranging from 180-200 gm were selected and provided ambient physical and physiological condition as per the standard protocol and all the experimental protocol was carried based on the guideline adopted by Mahavir Cancer Sansthan ethical comittee, Phulwarisariff Patna.

\section{Plant materials}

Dried leaves of Gymnema sylvestre.

\section{Preparation of ethanolic extract}

The dried plant materials i.e., leaf of Gymnema sylvestre blended to fine powder and then soaked with absolute ethanol and kept in dark to avoid from light for 48 hours in order to get the secondary metabolites dissolved in to the solvent. After 48 hours extract was filtered till the clear material appeared. The solvent containing secondary metabolite of both the plant was mounted on the vaccuma rotary evaporator at $40^{\circ} \mathrm{C}$. The extract was kept on the vaccuma rotary till the thick paste was not appeared devoid of any solvent material. The colloidal paste was lyophillysed in lyophyliser (Labconco, USA) and was stored in deep freezer at $\_80^{\circ}$ $\mathrm{C}$ until further use.

\section{Experimental Design}

Male healthy rats were utilized for the experimental work divided into five groups namely Normal control, Diabetic control, extract fed for 10 days, extract fed for 20 days, and extract fed for 30 days respectively. Each groups contained five rats. Normal rats were retained on the normal diet without extract. Except normal, all the rats were made diabetic and only those rats were considered for the experimental group which persisted diabetic condition after 10-12 days of Alloxan induction. After subsequent interval of the time different types of sample were collected for various tests.

\section{Induction of diabetes}

Diabetes was induced by repeated dose of Alloxan monohydrate $100 \mathrm{mg} / \mathrm{kg}$. b.wt in cold citrate buffer bearing $\mathrm{pH} 4.5$.

\section{Sample collection}

After the treatment of the extract for 10, 20, and 30 days respectively the tissues collected were for antioxidant quantification. For anti-oxidant analysis the tissue sample were subjected to preparation of post mitochondrial supernatant (PMS).

\section{Biochemical estimation}

Biochemical estimation includes plasma glucose (Glucose oxidase/peroxidase method by using systronic UV, Visible Spectrophotometer 119, India) (12), Serum insulin by ELISA (Robonik, Readwell Touch ${ }^{\mathrm{TM}}$, Automatic ELISA plate analyser, India), serum amylase (Direct Substrate Method) (13), serum lipase ( Turbidometric U.V. Method) (14), serum electrolyte by flame photometry (systronic 128, Ahmedabad, India), Alanine aminotransferase (ALT) Reitman and Frankel method and Aspartate aminitransferases (AST) Modified IFCC method.

\section{Hematology estimation}

Hematology estimation include Total RBC by using hayem's fluid, Total WBC, Hemoglobin (Cyanmethemoglobin method) (15), and differential count using polychromic solution containing Gention violet and Eosin manually by smear preparation.

\section{Antioxidant enzyme estimation}

Antioxidant parameters were carried out by the published standard literature like Estimation of Catalase was done by (16), estimation of total reduced Glutathione (GSH) (17), estimation of Glutathione Peroxiase (18), estimation of Glutathione-s-transferase by (19), and quantification of Superoxide dismutase (SOD) (20).

\section{Statistical Analysis}

Statistical analysis was done using Prism graph pad 3.0 software. Data are represented as mean \pm SD. Differences between groups were assessed using one way analysis of variance (ANOVA) followed by Tukey multiple range test, compared with entire column. Level of significance were expressed as, aindicates $\mathrm{P}<0.001,{ }^{\mathrm{b}}<0.01, \mathrm{cP}<0.05$, and $\mathrm{d} \mathrm{P}>0.05$ nonsignificant. 


\section{Results}

Table I. Effect of Gymnema sylvestre (GSE) $500 \mathrm{mg} / \mathrm{kg} . \mathrm{b} . \mathrm{wt}$ on fasting plasma glucose and serum insulin

\begin{tabular}{|c|c|c|}
\hline & Glucose $\mathbf{( m g / d l})$ & Insulin $(\boldsymbol{\mu I U} / \mathbf{m l})$ \\
\hline Normal Control & $97.80 \pm 5.63 \mathrm{a}$ & $8.22 \pm 0.58 \mathrm{a}$ \\
\hline Diabetic Control & $328.0 \pm 18.23 \mathrm{a}$ & $2.37 \pm 0.48^{\mathrm{a}}$ \\
\hline Diabetic + 10 Days GSE & $276.0 \pm 20.74 \mathrm{~b}$ & $3.74 \pm 0.2 \mathrm{~b}$ \\
\hline Diabetic + 20 Days GSE & $203.0 \pm 24.39 \mathrm{a}$ & $4.98 \pm 0.81 \mathrm{a}$ \\
\hline Diabetic + 30 Days GSE & $153.0 \pm 15.25 \mathrm{a}$ & $6.79 \pm 0.85 \mathrm{a}$ \\
\hline
\end{tabular}

Values are expressed as mean $\pm S D$ (Standard Deviation); aindicates $P<0.001,{ }^{b} P<0.01,{ }^{c} P<0.05$, and ${ }^{d} P$ $>0.05$ non- significant. one-way ANOVA was performed followed by Tukey multiple range test, compared with entire column.

Table II. Effect of Gymnema sylvestre (GSE) 500mg/kg.b.wt on pancreatic enzymes Serum amylase and lipase

\begin{tabular}{|c|c|c|l|l|}
\hline & Amylase (U/L) & Lipase (U/L) & ALT (U/L) & AST (U/L) \\
\hline Normal Control & $80.80 \pm 10.33^{\mathrm{a}}$ & $37.01 \pm 9.62^{\mathrm{a}}$ & $33.0 \pm 3.31^{\mathrm{a}}$ & $35.80 \pm 5.65^{\mathrm{a}}$ \\
\hline Diabetic Control & $350.0 \pm 23.02^{\mathrm{a}}$ & $170.0 \pm 11.51^{\mathrm{a}}$ & $125.4 \pm 10.74^{\mathrm{a}}$ & $115.4 \pm 10.74^{\mathrm{a}}$ \\
\hline Diabetic + 10 Days GSE & $318.0 \pm 14.83^{\mathrm{b}}$ & $146.0 \pm 17.10^{\mathrm{c}}$ & $98.20 \pm 12.81^{\mathrm{b}}$ & $108.8 \pm 10.66^{\mathrm{a}}$ \\
\hline Diabetic + 20 Days GSE & $268.0 \pm 11.51^{\mathrm{a}}$ & $118.0 \pm 16.81^{\mathrm{a}}$ & $75.80 \pm 65.3^{\mathrm{a}}$ & $90.50 \pm 9.68^{\mathrm{b}}$ \\
\hline Diabetic + 30 Days GSE & $184.0 \pm 9.61^{\mathrm{a}}$ & $91.0 \pm 9.61^{\mathrm{a}}$ & $61.0 \pm 6.51^{\mathrm{c}}$ & $75.00 \pm 5.7^{\mathrm{c}}$ \\
\hline
\end{tabular}
Values are expressed as mean $\pm S D$ (Standard Deviation); aindicates $P<0.001,{ }^{b} P<0.01,{ }^{c} P<0.05$, and ${ }^{d} P$ $>0.05$ non- significant. One-way ANOVA was performed followed by Tukey multiple range test, compared with entire column.

Table III. Effect of Gymnema sylvestre (GSE) 500mg/kg.b.wt on Superoxide, Glutathione, and Catalase

\begin{tabular}{|c|c|c|c|}
\hline & $\begin{array}{c}\text { Superoxide Dismutase } \\
\text { (SOD) (U/ml) }\end{array}$ & $\begin{array}{c}\text { Glutathione (GSH) } \\
\mathbf{( m g / m L )}\end{array}$ & $\begin{array}{c}\text { Catalase (CAT) } \\
\text { (mU/mg protein) }\end{array}$ \\
\hline Normal Control & $9.51 \pm 0.90^{\mathrm{a}}$ & $17.30 \pm 1.85 \mathrm{a}$ & $9.27 \pm 1.21 \mathrm{a}$ \\
\hline Diabetic Control & $4.25 \pm 0.45^{\mathrm{a}}$ & $7.67 \pm 0.66 \mathrm{a}$ & $2.42 \pm 0.43 \mathrm{a}$ \\
\hline Diabetic + 10 Days GSE & $4.88 \pm 0.39 \mathrm{a}$ & $9.38 \pm 1.40 \mathrm{~d}$ & $3.26 \pm 0.37 \mathrm{~d}$ \\
\hline Diabetic + 20 Days GSE & $5.84 \pm 0.38 \mathrm{a}$ & $12.44 \pm 1.07 \mathrm{a}$ & $4.73 \pm 0.29 \mathrm{a}$ \\
\hline Diabetic + 30 Days GSE & $7.54 \pm 0.19 \mathrm{~b}$ & $14.86 \pm 1.40 \mathrm{a}$ & $6.89 \pm 0.49 \mathrm{~b}$ \\
\hline
\end{tabular}

Values are expressed as mean $\pm S D$ (Standard Deviation); aindicates $P<0.001,{ }^{b} P<0.01,{ }^{c} P<0.05$, and ${ }^{d} P$ $>0.05$ non- significant. One-way ANOVA was performed followed by Tukey multiple range test, compared with entire column.

Table IV. Effect of Gymnema sylvestre (GSE) $500 \mathrm{mg} / \mathrm{kg}$.b.wt on Glutathione peroxidase, Glutathione-Stransferase, and Total thiol.

\section{Glutathione Peroxidase \\ (GPx) (nmol/NADPH oxidized/min)}

\begin{tabular}{|c|c|}
\hline Normal Control & $5.63 \pm 0.52$ a \\
\hline Diabetic Control & $1.78 \pm 0.39$ a \\
\hline Diabetic + 10 Days GSE & $2.67 \pm 0.46^{\mathrm{c}}$ \\
\hline Diabetic + 20 Days GSE & $3.61 \pm 0.33^{\mathrm{a}}$ \\
\hline Diabetic + 30 Days GSE & $4.22 \pm 0.37$ a \\
\hline
\end{tabular}

Glutathione-Stransferase ( $\mu \mathrm{mol}$ of GSH consumed/ $\mathrm{mg}$ protein/min)
$1.90 \pm 0.15$ a
$0.79 \pm 0.07$ a
$0.94 \pm 0.04 \mathrm{~d}$
$1.28 \pm 0.12$ a
$1.68 \pm 0.11^{\mathrm{c}}$
$5.16 \pm 0.69$ a
$1.31 \pm 0.21$ a
$2.33 \pm 0.19 \mathrm{~b}$
$3.45 \pm 0.22$ a
$4.22 \pm 0.48$ a

Total Thiol (nmol/NADPH oxidized/ min)

Values are expressed as mean $\pm S D$ (Standard Deviation); aindicates $P<0.001,{ }^{b} P<0.01,{ }^{c} P<0.05$, and $d P$ $>0.05$ non- significant. One-way ANOVA was performed followed by Tukey multiple range test, compared with entire column.

Table V. Effect of Gymnema sylvestre on the status of serum electrolyte in treated and non treated groups.

\section{Normal Control \\ Diabetic Control}

Diabetic + 10 Days GSE

Diabetic + 20 Days GSE

Diabetic + 30 Days GSE
Sodium (mmol/L)

$142.2 \pm 3.19^{\mathrm{a}}$
$131.0 \pm 2.23 \mathrm{a}^{\mathrm{a}}$
$134.04 \pm 3.20^{\mathrm{a}}$
$137.0 \pm 2.70^{\mathrm{a}}$
$140.4 \pm 2.19^{\mathrm{a}}$

Potassium (mmol/L)

$$
\begin{gathered}
4.08 \pm 0.3 \mathrm{a} \\
5.28 \pm 0.19 \text { a } \\
4.97 \pm 0.12 \mathrm{a} \\
4.7 \pm 0.15 \mathrm{a} \\
4.35 \pm 0.17 \mathrm{a}
\end{gathered}
$$

Values are expressed as mean $\pm S D$ (Standard Deviation); aindicates $P<0.001,{ }^{b} P<0.01,{ }^{c} P<0.05$, and $d P>0.05$ non- significant. One-way ANOVA was performed followed by Tukey multiple range test, compared with entire column. 
Kumud Ranjan Thakur et.al., Assessing the Hypoglycemic and anti-oxidative potential of Gymnema sylvestre in Diabetic rats

Table VI. . Effect of Gymnema sylvestre on the status of $\mathrm{RBC}, \mathrm{Hb}$, and $\mathrm{WBC}$ in treated and non treated groups.

\begin{tabular}{|c|c|c|c|c|}
\hline & $\begin{array}{l}\text { Total Erythrocyte } \\
\text { (million/mm3) }\end{array}$ & $\begin{array}{l}\text { Hemoglobin } \\
\text { (mg/dl) }\end{array}$ & $\begin{array}{l}\text { Total Leucocyte } \\
\text { (thousand } / \mathbf{m m}^{3} \text { ) }\end{array}$ & $\begin{array}{c}\text { Lymphocyte } \\
(\%)\end{array}$ \\
\hline Normal Control & $5.9 \pm 0.20 \mathrm{a}$ & $14.95 \pm 0.28$ a & $6.48 \pm 0.16^{a}$ & $45.0 \pm 4.12 \mathrm{a}$ \\
\hline Diabetic Control & $4.35 \pm 0.28 \mathrm{a}$ & $12.38 \pm 0.24 \mathrm{a}$ & $8.24 \pm 0.23 b$ & $58.0 \pm 2.55 \mathrm{a}$ \\
\hline Diabetic + 10 Days GSE & $4.64 \pm 0.29 \mathrm{~d}$ & $13.30 \pm 0.33 \mathrm{a}$ & $7.80 \pm 0.35 \mathrm{~d}$ & $54.60 \pm 2.79 \mathrm{~d}$ \\
\hline Diabetic +20 Days GSE & $4.93 \pm 0.20 \mathrm{c}$ & $13.69 \pm 0.27 \mathrm{a}$ & $7.46 \pm 0.30 \mathrm{a}$ & $51.40 \pm 2.70^{\mathrm{c}}$ \\
\hline Diabetic +30 Days GSE & $5.28 \pm 0.22 \mathrm{a}$ & $14.16 \pm 0.21 \mathrm{a}$ & $7.03 \pm 0.16 \mathrm{a}$ & $49.00 \pm 3.08 \mathrm{~b}$ \\
\hline
\end{tabular}

Values are expressed as mean $\pm S D$ (Standard Deviation); aindicates $P<0.001, b P<0.01, c P<0.05$, and $d P$ $>0.05$ non- significant. One-way ANOVA was performed followed by Tukey multiple range test, compared with entire column.

Table VII. Effect of Gymnema sylvestre on the status of differential leukocyte count in treated and non treated

\begin{tabular}{|c|c|c|c|c|c|}
\hline & groups. & & \\
\hline Normal Control & $51.40 \pm 2.40$ & $1.0 \pm 0.70$ & $0.50 \pm 0.54$ & $0.83 \pm 0.40$ \\
\hline Diabetic Control & $42.20 \pm 1.92$ & $1.80 \pm 0.83$ & $0.50 \pm 0.54$ & $0.50 \pm 0.54$ \\
\hline Diabetic + 10 Days GSE & $43.80 \pm 1.48$ & $2.80 \pm 0.83$ & $1.0 \pm 0.63$ & $0.66 \pm 0.51$ \\
\hline Diabetic + 20 Days GSE & $47.0 \pm 1.58$ & $3.40 \pm 0.54$ & $1.0 \pm 0.63$ & $1.0 \pm 0.63$ \\
\hline Diabetic + 30 Days GSE & $50.0 \pm 1.58$ & $2.40 \pm 0.89$ & $0.66 \pm 0.51$ & $1.0 \pm 0.89$ \\
\hline
\end{tabular}

Values are expressed as mean $\pm S D$ (Standard Deviation); aindicates $P<0.001, b P<0.01,{ }^{c} P<0.05$, and $d P$ $>0.05$ non-significant. One-way ANOVA was performed followed by Tukey multiple range test, compared with entire column.

\section{Discussion}

Recent reports of chemotherapeutics resistant in treatment of diabetes mellitus have forced the research community to look towards nature for the better remedy and hence the herbal drugs are emerging as a future hope in control of diabetes mellitus. The present study involved Gymnema sylvestre with the same intention. Considering this in view, a comprehensive study involving various anti-oxidative, biochemical, and hematological parameters was probed and validated.

Plasma blood glucose level plays a vital role in complications associated with diabetes like renal, eye, neurological damages. Contributors of the complications in diabetes are glycosylation of biomolecules, increased cellular oxidative tension, serum osmolality etc. In the present study, reduction in blood glucose concentration was achieved (56.44\%) $(p<0.001)$ after administration of phytochemical extracts on the $30^{\text {th }}$ days. Decrease in blood glucose level (65\%) was associated with enhanced insulin $(\mathrm{p}<0.001)$ (Table I) production and alleviation of oxidative stress. Insulin is the primary hormone involved in the regulation of blood glucose level. Alloxan induced diabetic rats showed nearly $(71.11 \%)(p<0.001)$ (Table I) decrease in insulin level. Significant recovery in insulin level was observed after 30 days of administration of phytochemical extracts. The results corroborates with previous findings (21).

Increased concentration of amylase and lipase in the present investigation in diabetic subjects beyond 3 times $(p<0.001)$ the normal rats indicates the condition of acute pancreatitis as per the Atlanta classification (22-24) after administration of the ethanolic herbal extract $(500 \mathrm{mg} / \mathrm{kg}$.b.wt) the normalization of the enzyme concentration to 2.09 times $(p<0.001)$ and 2.21 times $(p<0.001)$ (Table II)of amylase and lipase indicates amelioration of excessive oxidative stress, ischemia, and necrosis (25). Alanine aminotransferase (ALT) and Aspartate aminotransferase (AST) are the most commonly used indicators of cell necrosis led ischemia, toxicicity, and its elevation is due to leaking from the hepatic cell (26). Diabetic subjects showed mild increase in ALT (3.78 times) and AST (3.22 times) (Table II) the control value. Ethanolic extract of Gymnema sylvestre brought significant recovery in the concentration of tranaminases to a significant level. Recovery in ALT and AST indicates ameliorative property of extract in overcoming the necrosis caused by the oxidative stress due to prolonged hyperglycemia (27).

Superoxide dismutase (SOD) enzyme plays a significant role in cellular enzymatic defense system. SOD activity in diabetic rats significantly decreased by $55.3 \%(p<0.001)$ when compared with that in normal rats. Ethanolic extract administration rescued the concentration of superoxide dismutase to $48.38 \%$ $(\mathrm{p}<0.01)$ as compared to the diabetic rats. The results obtained are in agreement with previous studies (28). Hyperglycemia is usually concerned with metabolic disturbances affecting cellular redox potential, particularly, imbalanced NADPH/NADP+ ratio and reduced glutathione levels (29). The present study evidences decreased glutathione level to $55.31 \%$ $(\mathrm{p}<0.001)$ in diabetic group. Rats fed with the Gymnema sylvestre herbal extract restored the Glutathione level to $43.3 \%(\mathrm{p}<0.001)$ (Table III) as compared to the diabetic groups (30).

Catalase is essential for scavenging the voluminous and toxic hydrogen peroxide in the biological system (31). Diabetic rats registered 73.89\% $(\mathrm{P}<0.001)$ decrease in the catalase activity as compared to normal control but upon extract administration it regained concentration to $64.87 \%(\mathrm{P}<0.01)$ (Table III) as compared to diabetic rats. This restoration of the enzyme suggests ameliorating properties of the extract 
against inflammation, apoptosis, and necrosis caused by hyperglycemia and oxidative stress (32).

Glutathione peroxidase (GPx) plays a remarkable role in the reduction of lipid and hydrogen peroxides (33). Diabetic rats represented $68.38 \%$ reduction $(\mathrm{P}<0.001)$ in the GPx activity addresses increased hydrogen peroxide and tissue damage by activation inflammation by various molecular pathways (34). Increased peroxide stress was reduced to $57.81 \%$ $(\mathrm{P}<0.001)$ (Table III) on the $30^{\text {th }}$ days of extract administration as compared to the diabetic control. Glutathione-S-transferase (GST) countereacts with reactive oxygen species (ROS) by enzymatic conjugation with glutathione (GSH) (35). There was $58.42 \%(\mathrm{P}<0.001)$ decrease in glutathione $\mathrm{s}$ transferase enzyme in diabetic controlled rats while after treatment the concentration in context to diabetic group was increased to $52.97 \%(\mathrm{P}<0.05)$ (Table IV). Thiol/ disulfide homeostasis plays important vital roles in detoxification, antioxidant protection, and regulation of enzymatic activity and transcription factors, apoptosis, and cellular signal mechanisms (36). Total thiol registered $68.95 \%(p<0.01)$ recovery after $30^{\text {th }}$ day of extract administration against diabetic group with marked $74.1 \%(p<0.001)$ (Table IV) decrease in Total thiol concentration. The results were in congruence with (37).

Oxidative stress mediates inflammation and apoptosis in pancreatic tissues which is reflected by altered anti-oxidative enzymes. Alleviation of inflammation and apoptosis in diabetic rat pancreatic tissue was a result of extract, resulted in balanced antioxidative enzyme and reduced oxidative stress (38).

Decrease in the sodium ion $(7.87 \%) \quad(\mathrm{p}<0.001)$ concentration was noticed in diabetic group; it was either due to intestinal malabsorption or due to excessive excretion in urine which registered decreased serum sodium concentration however the value was maintained to the normal range after the herbal extract administration. Potassium ion being stable was little increased $(29.41 \%) \quad(p<0.001) \quad$ (Table V) but it is normal range in diabetic condition however this increase was insignificant and it doesn't give any reason to reach to any pathological condition but it was restored after extract administration.

$\mathrm{RBC}$ in diabetic rats was lying in the normal range but towards the lower extreme. The reason behind decrease in the RBC count may be its membrane modification and reduced $\mathrm{Na}+\mathrm{K}+\mathrm{ATPase}$ activity and high lipid peroxidation of the RBC membrane (39). Herbal extract administration led to the normalization of the same.This recovery was due to availability of ATP to the membrane and thus increased $\mathrm{Na}+\mathrm{K}+\mathrm{ATPase}$ activity to the cell which led to increased cell viability along with reduced peroxide stress and this finding can be correlated with results of (40).

Present research registered elevated WBC $(27.16 \%) \quad(p<0.01)$ count in diabetes which might be due excess fat storage, and low-grade inflammation [40]. Treatment with Gymnema sylvestre led to normalization of the WBC. Reduced hemoglobin $(17.19 \%)(p<0.001) \quad($ Table VI) concentrations are the common findings in diabetic condition. Study on the Alloxan induced diabetic rats were represented with lower hemoglobin, the present study correlates with (41). Challenged oxidative enzyme (Catalase) pertaining oxidative stress also mediates low hemoglobin in diabetic state (42). Ethanolic herbal extract of Gymnema sylvestre regained the normal level due to restoration of anti-oxidative enzyme.

The Lymphocyte and Neutrophil count was assessed in the all group to investigate the wellness of the rats during diabetic states. Slight increase in the lymphocyte and Neutrophil count was noticed in diabetic as compared to normal control.

Monocytes, Basophil, and Eosinophil are the other differential leukocyte cells. In the present research work neither diabetic rats showed any impact nor the treated group showed any significant result $(p>0.05)$ (Table VII) regarding alteration in these parameters however there are certain evidences which supports connection of the diabetic complication with the mentioned parameters need to be probed and evaluated on a large sample size.

\section{Conclusion}

Diabetes is a multifactorial disorder which couldn't be controlled by synthetic drugs which are single target specific. Alternate and complementary medicine in the form of phytochemical has gained attention of the entire research community. Present study showed hypoglycemic properties of Gymnema sylvestre extract (GSE) by decreasing glucose concentration and increased insulin production. This was probably due to histoarchitectural remodeling of pancreatic tissue which can be evidenced by decreased oxidative load in the tissues. Antioxidative properties were more convincing in the pancreatic tissue. Restoration of pancreatic juices like amylase and lipase was little convincing which needs to be validated on a large sample size. Restoration of ALT and AST to an extent indicated hepatoprotective nature of extract. However the hematological study suggests fluctuation of $\mathrm{RBC}, \mathrm{WBC}, \mathrm{Hb}$, and lymphocyte due to hyperglycemia and oxidative stress. Other differential cells didn't impacts more because they didn't show any significant alteration.

\section{Acknowledgement}

Authors are thankful to DST Inspire for providing fellowship, Kumar Sayrav (Technical officer) for technical support, Mr. Vikas kumar, and Mr. Ravinder for helping in research activities in the Department of Biochemistry.

\section{Conflict of interest}

Authors declare no conflict of interest regarding publication or any other activity related to this article.

\section{References}

1. Unnikrishnan R, Anjana RM, Mohan V. Diabetes mellitus and its complications in India. Nat Rev Endocrinol. 2016; 12 (6):357-370. 
2. Zimmet P, Alberti KG, Magliano DJ, Bennett PH Diabetes mellitus statistics on prevalence and mortality: facts and fallacies. Nat Rev Endocrinol. 2016; 12 (10):616-622.

3. Pradeepa R, Mohan V. Prevalence of type 2 diabetes and its complications in India and economic costs to the nation. Eur J Clin Nutr. 2017; 71(7):816-824.

4. Román-Pintos LM, Villegas-Rivera G, RodríguezCarrizalez AD, Miranda-Díaz AG, Cardona-Muñoz EG. Diabetic Polyneuropathy in Type 2 Diabetes Mellitus: Inflammation, Oxidative Stress, and Mitochondrial Function. J Diabetes Res: 2016. 3425617

5. He L, He T, Farrar S, Ji L, Liu T, Ma X. Antioxidants Maintain Cellular Redox Homeostasis by Elimination of Reactive Oxygen Species. Cell Physiol Biochem; 2017 44(2):532-553.

6. Ighodaro $\mathrm{O} \mathrm{M}$, Adeosun A $\mathrm{M}$, Akinloye $\mathrm{O}$ A. Alloxan-induced diabetes, a common model for evaluating the glycemic-control potential of therapeutic compounds and plants extracts in experimental studies. Medicina (Kaunas). 2017; 53 (6):365-374.

7. Habtezion A. Inflammation in acute and chronic pancreatitis. Curr Opin Gastroenterol. 2015; 31 (5):395-399.

8. Singh P, Garg PK. Pathophysiological mechanisms in acute pancreatitis: Current understanding. Indian J Gastroenterol. 2016; 35 (3):153-166.

9. Banjari I, Misir A, Pavlić M, Herath PN, Waisundara VY. Traditional Herbal Medicines for Diabetes Used in Europe and Asia: Remedies From Croatia and Sri Lanka. Altern Ther Health Med. 2019; 25 (3):40-52.

10. Oguntibeju OO. Hypoglycaemic and anti-diabetic activity of selected African medicinal plants. Int $J$ Physiol Pathophysiol Pharmacol. 2019; 11(6):224-237.

11. Komalavalli $\mathrm{N}$ and Rao MV, In vitro micropropagation of Gymnema sylvestre: multipurpose medicinal plant. PlantCell Tiss Org. 2000; 61:97-105.

12. Trinder P. Determination of Glucose in Blood Using Glucose Oxidase with an Alternative Oxygen Acceptor. Ann. din. Biochem. 1969; 6; 24.

13. IFCC methods for measurement of catalytic concentration of enzymes. J.Clin.chem.Acta. 1999; 281:5

14. Ziegenhorn J, Neumann U, Knitsch KW, and Zwez W. Determination of serum lipase. Clin. Chem. 1979; 25, 1067.

15. David L Drabkin, and Harold J Austin.Pectrophotometric studies: ii. Preparations from washed blood cells; nitric oxide hemoglobin and sulfhemoglobin. J. Biol. Chem. 1935; 112: 51-.65

16. Sinha AK. Colorimetric assay of catalase. Anal Biochem. 1972; 47(2):389-94.

17. Boyne AF, Ellman GL. A methodology for analysis of tissue sulfhydryl components. Anal Biochem. 1972; 46(2):639-53.
18. Rotruck JT, Pope AL, Ganther HE, Swanson AB, Hafeman DG, Hoekstra WG. Selenium: biochemical role as a component of glutathione peroxidase. Science. 1979; 179 (4073):588-90.

19. Habig WH, Pabst MJ, Jakoby WB. Glutathione-Stransferases. The first Journal of Biochemistry. 1974; 47: 469-74.

20. Marklund, S, \& Marklund, G. Involvement of the superoxide anion radical in the autoxidation of pyrogallol and a convenient assay for superoxide dismutase. Eur J Biochem. 1974; 47(3):469-74.

21. Kumar V, Bhandari U, Tripathi CD and Khanna G, Evaluation of anti-obesity and cardioprotective effect of Gymnema sylvestre extract in murine model. Indian J Pharmacol. 2012; 44:607-613.

22. Pandiri AR. Overview of exocrine pancreatic pathobiology. Toxicol Pathol. 2014; 42 (1):207-216.

23. Lankisch PG, Apte M, Banks PA. Acute Pancreatitis, Lancet. 2015; 386 (9988), 85-96.

24. Banks PA, Bollen TL, Dervenis C, et al. Classification of acute pancreatitis--2012: revision of the Atlanta classification and definitions by international consensus. Gut. 2013; 62 (1):102-111.

25. Kamath V, Rajini PS. Altered glucose homeostasis and oxidative impairment in pancreas of rats subjected to dimethoate intoxication. Toxicology. 2007; $231(2-3): 137-146$.

26. Dufour DR, Lott JA, Nolte FS, et al. Diagnosis and monitoring of hepatic injury. II. Recommendations for use of laboratory tests in screening, diagnosis, and monitoring. Clin Chem 2000;46:2050-68.

27. Daisy P, Eliza J, Mohamed Farook KA. A novel dihydroxy gymnemic triacetate isolated from Gymnema sylvestre possessing normoglycemic and hypolipidemic activity on STZ-induced diabetic rats. J Ethnopharmacol. 2009;126(2):339-344.

28. Al-Romaiyan A, Liu B, Persaud S, Jones P. A novel Gymnema sylvestre extract protects pancreatic betacells from cytokine-induced apoptosis. Phytother Res. 2020;34(1):161-172.

29. Díaz-Flores M, Ibáñez-Hernández MA, Galván RE, et al. Glucose-6-phosphate dehydrogenase activity and NADPH/NADP+ ratio in liver and pancreas are dependent on the severity of hyperglycemia in rat. Life Sci. 2006; 78 (22):2601-2607.

30. Tiwari P, Mishra BN, Sangwan NS. Phytochemical and pharmacological properties of Gymnema sylvestre: an important medicinal plant. Biomed Res Int. 2014; 2014:830285.

31. Sepasi Tehrani H, Moosavi-Movahedi AA. Catalase and its mysteries. Prog Biophys Mol Biol. 2018; 140: 5-12.

32. Arokoyo DS, Oyeyipo IP, Du Plessis SS, Aboua YG. Antioxidant Activities of Basella alba Aqueous Leave Extract In Blood, Pancreas, and Gonadal Tissues of Diabetic Male Wistar Rats. Pharmacognosy Res. 2018; 10(1):31-36.

33. Arthur JR. The glutathione peroxidases. Cell Mol Life Sci. 2000; 57(13-14):1825-1835.

34. Siddiqui A, Desai NG, Sharma SB, Aslam M, Sinha UK, Madhu SV. Association of oxidative stress and 
inflammatory markers with chronic stress in patients with newly diagnosed type 2 diabetes. Diabetes Metab Res Rev. 2019; 35(5):e3147.

35. Sharma M, Gupta S, Singh K, et al. Association of glutathione-S-transferase with patients of type 2 diabetes mellitus with and without nephropathy. Diabetes Metab Syndr. 2016; 10(4):194-197.

36. Circu ML, Aw TY. Reactive oxygen species, cellular redox systems, and apoptosis. Free Radic Biol Med. 2010;48:749-62.

37. Köseoğlu H, Alışık M, Başaran M, et al. Dynamic thiol/disulphide homeostasis in acute pancreatitis. Turk J Gastroenterol. 2018; 29(3):348-353.

38. Adam SH, Giribabu N, Kassim N, et al. Protective effect of aqueous seed extract of Vitis vinifera against oxidative stress, inflammation and apoptosis in the pancreas of adult male rats with diabetes mellitus. Biomed Pharmacother. 2016; 81: 439-452.
39. Chakraborty A, Chowdhury S, Bhattacharyya M. Effect of Metformin on oxidative stress, nitrosative stress and inflammatory biomarkers in type 2 diabetes patients. Diabetes Res Clin Pract, 2011; 93(1):56-62.

40. Gilad Twig, Arnon Afek, Ari Shamiss, Estela Derazne, Dorit Tzur, Barak Gordon, and Amir Tirosh. White Blood Cells Count and Incidence of Type 2 Diabetes in Young Men. Diabetes Care. 2013 Feb; 36(2): 276-282.

41. Thomas MC, MacIsaac RJ, Tsalamandris C, Power D, Jerums G. Unrecognized anemia in patients with diabetes: a cross-sectional survey. Diabetes Care. 2003; 26:1164-1169.

42. Góth L, Tóth Z, Tarnai I, Bérces M, Török P, and Bigler WN, "Blood catalase activity in gestational diabetes is decreased but not associated with pregnancy complications," Clinical Chemistry, vol. 51, no. 12, pp. 2401-2404, 2005. 